УДК 327.88(497.1:439)"1948/1953"

314.151.3-054.72(=163.3/.6)(439)"1948/1953"

Оригинални научни рад

Примљен: 3. 7. 2017.

Прихваћен: 22. 12. 2017.

Péter VUKMAN

Institute of History, University of Szeged (Hungary)

vuximaxi@gmail.com

\title{
Political activities of ibeovci emigrants in Hungary (1948-1953)*
}

\begin{abstract}
As a consequence of the outbreak of the Soviet-Yugoslav conflict, Cominform emigrant communities were established in the Soviet Union and in Eastern Europe, including Hungary. The emigrants took an active part in the ongoing anti-Titoist propaganda campaign. This paper focuses on Lazar Brankov, the first leader of ibeovci emigrants in Hungary, his political activities and his role in organizing the emigrants' community in Hungary. Special emphasis is placed on their propaganda activities and the relationship between the emigrants and the Hungarian authorities. The article is based on archival research that was carried out at Hungarian archives.
\end{abstract}

Key words: Soviet-Yugoslav conflict, Yugoslav-Hungarian relationships, ibeovci emigrants, emigrants, Lazar Brankov

In early 1948, Stalin opened a "new cold war front" - this time within the Communist movement against Yugoslavia. This rapidly and dramatically escalating tension between the Soviet Union and Yugoslavia resulted in a complete isolation of Yugoslavia within the Communist sphere of the world. Economic blockade, military pressure and border incidents became a commonplace and anti-Titoist show trials took place in Albania, Bulgaria and Hungary. Moreover, the Soviet Union and its Eastern European satellites started a vigorous psychological and propaganda

* My research on the history of ibeovci emigrants in Hungary was funded by the Hungarian Scientific Research Fund (OTKA PD 108386). 
campaign against Tito and the leadership of the Communist Party of Yugoslavia (CPY). ${ }^{1}$

As an unexpected consequence of the conflict, so called "revolutionary", "Cominformist" or "ibeovci" emigrant communities were established in the Soviet Union and Eastern European communist countries. ${ }^{2}$ They originated from three different categories. The first comprised those Yugoslav citizens who had already lived in the Soviet Union and its satellite states when the Soviet-Yugoslav conflict started to escalate. Most of them were students who studied at different universities and military academies, the majority of them in the Soviet Union and Czechoslovakia. The second group comprised those Yugoslav diplomats who chose to emigrate during the escalation of the conflict. The third group consisted of those Yugoslavs who illegally crossed the Yugoslav border because they were strong supporters of Stalinist ideas. ${ }^{3}$

1 For the causes and consequences of the Soviet-Yugoslav conflict see: Leonid Gibianskii, "The Soviet Bloc and the Initial Stage of the Cold War. Archival Documents on Stalin's Meetings with Communist Leaders of Yugoslavia and Bulgaria, 1946-1948", Cold War International History Project Bulletin, March, (1998), 112-134; Leonid Gibianski, "The 1948 Soviet-Yugoslav Conflict and the Formation of the 'Socialist Camp' Model", The Soviet Union in Eastern Europe, 1945-1989, eds Odd Arne Westad, Sven Holtsmark, Iver B. Neumann, (New York: St. Martin's Press, 1994), 26-46; Jeronim Perović, "The Tito-Stalin Split. A Reassessment in Light of New Evidence", Journal of Cold War Studies 2, (2007), 32-63; Svetozar Rajak, "The Cold War in the Balkans, 1945-1956", The Cambridge History of the Cold War, Vol. I, eds Melvyn P. Leffler, Odd Arne Westad, (Cambridge: Cambridge University Press, 2010), 198-220, especially from 208.

2 For the history of ibeovci emigrants in Eastern Europe see: Petar Dragišić, "Napred List jugoslovenskih emigranata (pristalica Kominforma) u Bugarskoj", Tokovi istorije 3-4/2005, 125-142; Момчило Митровић, Слободан Селинић, “Југословенска информбироовска емиграција у источноевропским земљама, 1948-1964", Тоkovi istorije 1-2/2009, 31-54; Petar Dragišić, Jugoslovensko-bugarski odnosi 19441949, (Beograd: INIS, 2007), 232-250; Slobodan Selinić, Jugoslovensko-čehoslovački odnosi 1945-1955, (Beograd: INIS, 2010), 355-444; Ondřej Vojtěchovsky, Z Prahy proti Titovi! Jugoslovánská prosovětská emigrace v Česhoslovensku (Praha: Filozofická fakulta Univezity Karlovy, 2012). - Vojtěchovský's monograph has recently been published in Zagreb: Ondřej Vojtěchovský, Iz Praga protiv Tita: Jugoslavenska informbiroovska emigracija u Čehoslovačkoj (Zagreb: Srednja Europa, 2016). For the ibeovci emigrants in Hungary see: Vukman Péter, "Harcban Tito és Rankovics klikkje ellen"Jugoszláv politikai emigránsok Magyarországon (1948-1980), (Budapest-Pécs: ÁBTLKronosz, 2017), in Serbian: Péter Vukman, "Jugoslovenski politički emigranti u Mađarskoj (1948-1949)”, Mađari i Srbi sa dve strane promenjive granice 1941-1948, Tematski zbornik radova, ur. Hornyák Árpád, Zoran Janjetović, Bíró László, (Budapest: MTA BTK Történettudományi Intézete, 2016), 351-383.

3 Ivo Banac, With Stalin Against Tito. Cominformist Splits in Yugoslav Communism, (Ithaka-London:Cornell University Press), 222-223; Митровић, Селинић, “Југословенска 
Their collective was organized in Hungary, too. Based on contemporary Hungarian archival sources, they were organized in a rather small and closed community. Between 1948 and 1953, their number was no more than 132. The emigrants' community in Budapest served as a useful tool in everyday propaganda warfare against Yugoslavia. They wrote and distributed different articles in emigrant papers, and participated in daily radio broadcasts in Yugoslavia.

However, a detailed analysis of every aspect of this community would exceed the limits of a scientific article. Therefore, the aim of this paper is to provide a reader with an overview of their political activities and their relationship with Hungarian authorities. The first part of the article focuses on Lazar Brankov, the first and most important leader of ibeovci emigrants in Hungary, and his role in organizing the life and political activities of this community. The second part of the article deals with the emigrants' political activities while the final chapter highlights the life aspects of emigrants in Hungary under the fourfold control.

\section{Lazar Brankov, the first leader of ibeovci emigrants in Hungary}

One of the most important steps in the formation of the emigrants' community in Hungary took place on 25 October 1948 when Lazar Brankov, chargé d'affaires of the Yugoslav embassy in Budapest, emigrated on his free will and probably with the full knowledge of the Hungarian and Soviet leaders. ${ }^{4}$ Six other diplomats and employees of the embassy followed on the same day, and two others the day after that. In those two days, 14 new members were added to the emigrants' community that was currently taking shape. ${ }^{5}$

информбироовска емиграција", 35. For the Yugoslav students who studied abroad see also: Мирослав Перишић, Од Стаљина ка Сартру. Формирање југословенске ингелигенције на европским универзитетима 1945-1958, (Београд: Завод за уџбенике, 2012), 177-220.

4 For the life and political activities of Lazar Brankov in English see: Péter Vukman, "A Yugoslav Diplomat in Hungary: Lazar Brankov (1945-1949)", Vojvođanski prostor u kontekstu Evropske istorije, ur. Vladan Gavrilović, Svetozar Boškov, (Novi Sad: Filozofski fakultet u Novom Sadu, 2014), 513-524; Péter Vukman, "Lazar Brankov and the Yugoslav Communist Emigrants in Hungary (1948-49)”, Razprave in Gradivo. Treatise and Documents, Vol. 73, No. 1, (2014), 67-85.

5 The National Archives of Hungary (MNL OL) M-KS 276, f. 68, cs. 67, ő. e. 21. - Two of the diplomats, namely press secretary Ozren Krstonošić and vice-consul Branislav Doroslovački, had closer relations with Brankov. All three of them were born at Stari Bečej, and owed their posts at the embassy to Brankov's personal intervention in ear- 
Brankov's emigration was more than a simple desertion. In this way, Mátyás Rákosi, secretary general of the HWP, got hold of a diplomat of high stature and political calibre, whom he could use during the "fight" against Tito and the Yugoslav Communist leadership. With his former political activities and reputation, Brankov could easily be displayed as a potential leader of an all-emigrant organization or as a member, or even the head of a Yugoslav government in exile. Moreover, by putting Brankov in the middle of a creative stage of the anti-Titoist propaganda warfare, Rákosi could demonstrate the „deviance of the Titoist system” to the Hungarian public. The name of the chargé d'affaires of the Yugoslav embassy was well known in Hungary. Brankov, who was born in Stari Bečej in Vojvodina and could speak Hungarian fairly well, had been continuously living in the country since February 1945 when he was appointed to the Yugoslav mission to the ACC. From then onwards, he held important positions, first at the military mission, and later at the Yugoslav embassy. He had a role in many important issues affecting the two neighbouring countries, including the extradition of war criminals, the reparations, and the real or imagined complaints of the South Slavic minorities in Hungary. After the expulsion of the Ambassador Karlo Mrazović, he became the highest ranking Yugoslav diplomat at the embassy as chargé d'affaires. At the same time, he had access to the leading political and party circles. Therefore, it was not surprising that Rákosi himself had been trying to persuade him to emigrate since August $1948 .^{6}$

After he had emigrated, Brankov immediately took an active part in the ongoing propaganda warfare against Yugoslavia. He made speech-

ly 1947. Also, it was Brankov who persuaded them to follow him into exile, where both of them took an active role in the anti-Titoist work of the emigrant community. Péter Vukman, "Négy óbecsei kommunista diplomata Magyarországon. Lazar Brankov, Živko Boarov, Branislav Doroslovački és Ozren Krstonošić politikai tevékenysége”, Bácsország 2, (2011), 136-144.

6 For this see: Archives of Yugoslavia (Arhiv Jugoslavije - AJ), F. 507, CK SKJ IX-75/I-28. Some of the archival documents also suggest that Brankov might have emigrated with the knowledge and assistance of the CPSU. Also in August 1948, Brankov wrote a letter about his dilemmas to the Soviet communists and had had a meeting with Soviet diplomats in October, shortly before he emigrated. He recalled it in September 1954 as such: "The secretary of the Soviet embassy let me know their decision in the middle of October. At first, he asked me what I was intent to do, to go back [to Yugoslavia] or to emigrate. I answered that it made no difference to me, use me as it serves best the case [e. g. anti-Titoist campaign]. He then replied that according to their decision, I should emigrate." Historical Archives of the Hungarian State Security, Budapest (ÁBTL), 2.1. I/109-a, 224-225. 
es against Tito at mass rallies, including the congress of the Democratic Alliance of Southern Slavs in Hungary (MDDSZ) in Baja on 14 November 1948; he wrote articles in the party daily Szabad Nép and in the emigrants' paper Nova Borba; and he gave interviews "on the guilty deviation of the Titoist clique" to the journal of the Hungarian-Yugoslav Society (Déli Csillag) and Radio Budapest. The Hungarian Communist leadership also sent him to agitate among the South Slavic minorities in Hungary and propagate the official standpoint concerning Tito and the Yugoslav policies. ${ }^{7}$

It is natural that the propaganda machines of the Soviet Union and its Eastern European satellites tried to use each emigration and desertion for their own benefit. Their aim was to discredit the Yugoslav system and to emphasize the improper nature and deviation of Tito's policy from the official Soviet line. Brankov's emigration launched a whole series of note exchanges between the two neighbouring countries. Between 26 October and 10 November Yugoslavia sent eight notes to the Hungarian ministry of foreign affairs. ${ }^{8}$ Following his emigration, the total of 12 diplomats were expelled: nine from the Yugoslav embassy in Budapest and three Hungarian diplomats from Belgrade. ${ }^{9}$

Apart from the officially recurrent propaganda interviews and speeches, Brankov took a more serious part in the anti-Yugoslav campaign and immediately set to the task of organizing the emigrant community. After the discussions he had had in Prague with the leaders of the local emigrants, Brankov wrote a four-point working plan on 12 November in which he proposed relocating the headquarters of the emigrants' paper, Nova Borba to Budapest and establishing three logistic bases for its more efficient distribution close to the Yugoslav-Hungarian border, in the areas of Szeged, Pécs and Nagykanizsa. He also suggested that the MDDSZ and its paper, Naše novine, should be more involved in anti-Titoist propaganda warfare, and that the Serbian language program of Radio Budapest should be quadruplicated and the standard of its programs improved. Brankov also found it important that the cooperation between the emigrants and

7 Vukman, "Harcban Tito és Rankovics klikkje ellen", 51-54.

8 MNL OL XIX-J-1-k-Jugoszlávia-1/a-0218/1948, (1.d.); MNL OL XIX-J-1-k-Jugoszlávia-3/i-0224/1948, (1.d.), 0269/1948; MNL OL XIX-J-1-j-Jugoszlávia-3/c-796/ $\mathrm{pol} / \mathrm{res} / 1948$, (3.d.).

9 Altogether 40 Yugoslav diplomats and employees were expelled from Hungary between 6 August 1948 and 1 February 1950. White Book on Aggressive Activities by the Governments of the USSR, Poland, Czechoslovakia, Hungary, Rumania, Bulgaria and Albania towards Yugoslavia, (Beograd: Ministry of Foreign Affairs of the Federal People's Republic of Yugoslavia, 1951), Appendix 12, 465. 
the general public through the different press organs and radio programs be as wide as possible. His proposals were discussed and his argumentation accepted by the Secretariat of the HWP on 24 November 1948, except that it recommended the establishing of a temporary instead of a permanent editorial board. ${ }^{10}$ The Political Committee accepted nearly all Brankov's suggestions at the meeting that was held the following day. ${ }^{11}$

While being involved in related tasks, Brankov considered the South Slavic radio programs had a high priority. Still, his cooperation with the leaders of Radio Budapest was not smooth. In his memorandum to the Secretary of the HWP on 12 January 1949, Brankov resented the fact that the emigrants had not been involved in the preparation of the Serbo-Croat radio programs, had been left out from the decision-making process and had not been regularly consulted on the programs being broadcasted. Brankov also raised objections to the planned South Slavic radio programs. Instead of rather varied and entertaining programs, he suggested that the articles and theoretical papers of the emigrant press be read, on Radio Moscow in particular. He also recommended that a short, soul-stirring text, containing references to the "basic conclusions of Tito's betrayal", should be read before each broadcast. ${ }^{12}$

The everyday working relations between the emigrants and the leaders of the radio did not improve. In late April, Brankov protested because he was not sufficiently involved in the editorial work and because they did not broadcast the programs previously agreed on. He also argued that the weekly meetings of the editorial board were too short, the texts were not accurately translated into Serbian, and resented the fact that not even one copy of the Yugoslav papers was available for the emigrants. ${ }^{13}$ Having accepted Brankov's critical remarks, Rákosi ordered that Brankov must receive the utmost opportunities to carry out his work - "under sufficient control". ${ }^{14}$

Besides the South Slavic radio programs, another important method for propagating the Soviet standpoint was the illegal circulation of pamphlets, leaflets and brochures in the Yugoslav territory, including the copies of the emigrants' papers. Brankov also insisted that the emigrants establish connections with the members of the Yugoslav embassy in $\mathrm{Bu}-$

10 MNL OL M-KS 276, f. 68, cs. 16, ő. e. 54-57.

11 MNL OL M-KS 276, f. 53, cs. 15, ö. e. 3. and 18.

12 MNL OL M-KS 276, f. 54, cs. 30, ö. e. 29-30.

13 MNL OL M-KS 276, f. 66, cs. 35, ö. e. 71-76.

14 MNL OL M-KS 276, f. 66, cs. 35, ő. e. 71. 
dapest and the Yugoslav citizens who were living in the Hungarian capital (over 600 of them), improve their activities and carry out more tasks among the South Slavic minorities, whom he regarded as the outposts of Titoist propaganda. Therefore, he considered the role of the teachers who taught at minority schools especially important. ${ }^{15}$

During the organizational work, Brankov participated in important meetings with other ibeovci emigrant leaders, for example Pero Popivoda, wartime chief of staff of the Titoist partisans, and Radonja Golubović, former Yugoslav ambassador to Romania. The main aim of these meetings was to synchronize the activities of the emigrant leaders. Brankov had talks with Popivoda and Golubović in Bucharest in the period from 15 January to 7 February 1949. During their discussions, the three emigrant politicians analysed the situation of the emigrant communities and passed a resolution on strengthening the emigrant organizations. Therefore, they decided to establish a kind of an action committee whose main task was to improve the agitation and propaganda warfare, raise the quality of Nova Borba and solve certain problems concerning the radio broadcasts. ${ }^{16}$ Brankov's report on his discussions and his suggestions were dealt by the party secretariat of the HWP on 16 February. Among other things, it decided to appoint Brankov to the position of political advisor of the South Slavic language programs of Radio Budapest. Only one, still rather important, condition was added: Brankov must hold preliminary discussions on the theoretical topics with Mihály Farkas, Minister of National Defence and member of the Central Directorate and Political Committee of the HWP. ${ }^{17}$

Brankov apparently performed an increasing number of tasks; therefore, his arrest as a "Titoist agent" came as a huge surprise. The circumstances of his arrest were rather confusing. The Hungarian authorities had probably begun to plan his arrest as early as in the spring of 1949, but the Soviet cadres objected to it. Still, Brankov was arrested in the Soviet capital on 21 June $1949 .{ }^{18}$ His role of an emigrant leader ended here, although he had another, much more important role to perform in the anti-Titoist propaganda campaign later that year. (This issue shall be assessed later in the paper.)

\footnotetext{
15 MNL OL M-KS 276, f. 54, cs. 30, ő. e. 31-32.

16 MNL OL M-KS 276, f. 54, cs. 30, ö. e. 25-27.

17 MNL OL M-KS 276, f. 54, cs. 30, ő. e. 4.

18 ÁBTL 2.1. I/109, 149. and 272.
} 


\section{The political activities of ibeovci emigrants in Hungary}

The political emigrants, in general, showed three correlative types of activities in their "fight” against Tito and the CPY leadership: (1) they actively participated in the propaganda warfare against Yugoslavia through writing and distributing different printed material, e.g. journals and leaflets, and working at the South Slavic sections of the nationwide radio stations; (2) they took steps in order to establish an alternative ("real") communist party - with the possibility of a government-in-exile; and (3) they carried out different subversive activities in Yugoslavia. Based on former Yugoslav sources, 98 emigrant centres were established to coordinate their political activities - 35 of them in the Soviet Union, 17 in Bulgaria, 13 in Romania, 12 in Czechoslovakia, 12 in Hungary, and 9 in Albania. ${ }^{19}$ Unfortunately, in Hungarian archival sources, no reference can be found to these emigrant centres; they therefore might refer to the regional departments of the State Protection Authority (ÁVH) and the border patrol police. In Hungary, the emigrants took an active part in the anti-Titoist propaganda warfare. They participated in the editorial work of the South-Slavic language department of Radio Budapest, and more importantly, they wrote articles for several daily or weekly papers and periodicals condemning Tito's internal and foreign policy. The emigrants also carried out different subversive activities in Yugoslavia and they were used as a primary source of information, too, especially at the beginning of the Soviet-Yugoslav conflict.

It must be noted here that the emigrants' community in Hungary did not play the leading role within the ibeovci emigrants' communities. It was Lazar Brankov who had the necessary gift and aptitude to become one of the leaders of the whole community. After his arrest, the emigrants in Hungary were short of such a talent. Therefore, they were of secondary importance to the emigrants' communities in Moscow and Prague. For example, Nova Borba was first published in Prague on 25 September 1948, years earlier than the emigrants' own paper in Hungary (Za ljudsko zmago). Even its editor in chief, Boris Verstovšek, secretary of Yugoslav delegation to the UN (January-June 1948), was sent from Czech capital by the order of Pero Popivoda, but not even he was considered entirely reliable by the Hungarian authorities. It is also true that both communities lived

19 Радојица Лубурић, “Југословенска информбировска емиграција између илузија и стварности (1948-1953)”, Istorijski zapisi LXX, (1997), 5. 
their lives under manifold control and their main task was to produce and distribute propaganda material against Tito's regime. ${ }^{20}$

It should also be noted that the anti-Titoist propaganda warfare and scandal-mongering were not reduced only to the activities of the ibeovci emigrants and neither were they the ones who took the leading part therein. For Rákosi and the HWP leadership, the emigrants were important as a relatively cheap tool that was easy to use in order to keep the anti-Titoist public opinion on pilot light without risking the further escalation of the conflict. The broadcasting of South Slavic radio programs, writing of articles for different periodicals and distribution of brochures were important not only for the propaganda warfare against Tito and the CPY leadership but also because it could strengthen the morale and awareness of shared affinities among the emigrants themselves.

The transmission of South Slavic radio programs to Yugoslav territory steadily increased, both in the number and duration of the programs. Most of them were transmitted from Moscow and Sofia. ${ }^{21}$ In Hungary, Radio Budapest started the transmission of its regular Serbo-Croatian programs on 30 August 1948, though quite short and as part of its late-night program. ${ }^{22}$ In order to reach the widest audience possible, the authorities started to consider the possibility of short-wave transmission to Yugoslav territory in the spring of 1949 but this idea encountered serious technical and financial difficulties. ${ }^{23}$ Still, Radio Budapest finally started the transmission of short-wave radio programs; the South Slavic section of the Short-Wave Department produced 145 minute-long daily program in April $1951 .{ }^{24}$ On the other hand, the second, short-wave length program of Radio Budapest (Radio Petőfi) could have been received only in Slovenia and in the northern regions of Yugoslavia, therefore, only a much shorter

20 Vukman, "Harcban Tito and Rankovics klikkje ellen", 124, 148. For the propaganda activities of the Prague community see: Vojtěchovsky, Z Prahy proti Titovi!, 121-143.

21 Митровић, Селинић, “Југословенска информбироовска емиграција”, 41.

22 From November 1948 the ministry of foreign affairs and the Hungarian embassy in Belgrade joined in the preparation of the radio programs. The main task of the embassy was to provide news with sufficient quality and quantity. Although the embassy considered the political value of the news reports satisfactory, it had already complained about their lack of actuality. MNL OL XIX-J-4-a 8. d. 220/pol-1948. p. 120.

23 MNL OL XIX-J-4-a 12. d.139/szig.biz-1952.p. 209-211. and 12.d.104/szig-biz-1952. p. 213-214.

24 MNL OL M-KS 276, f. 98, cs. 115, ő. e. 3. 
program (65 minutes a day) of the first station (Radio Kossuth) could have been heard in all parts of the country. ${ }^{25}$

There is only insufficient information about the number and editorial activities of the ibeovci emigrants. It is certain that six emigrants were employed full-time at Radio Budapest in September 1951 while others wrote articles that were broadcasted in the program. However, the HWP considered the cost of employment of even these six emigrants too much as their work lacked the expected standard. It criticised not only the behaviour of the emigrants, which the party leaders regarded as passive and destructive, but also the negligence during their work and the poor quality of their articles. As a solution, the HWP suggested that at least some of the emigrants be dismissed. ${ }^{26}$ Although dismissals and relocations did take place, the number of the editorial staff was not reduced. The editorial board consisting of six emigrants became permanent, although relocations did take place in later years, too. ${ }^{27}$

Another effective propaganda tool as well as a useful medium in the anti-Titoist mud-slinging was the printed press. It was the emigration of Lazar Brankov that received the widest publicity in matters related to the ibeovci emigrants in Hungary as Rákosi wanted to exploit and utilize it as much as possible. Therefore, no less than seven articles were published on this topic in Szabad Nép, the official party journal, between 28 October and 16 November 1948. The ibeovci community in Hungary never received such public attention in later years. Their lives and political activities rarely had any news value. Apart from a few examples, the life and fate of the ibeovci community in Hungary was rarely worth publishing in the Hungarian-language papers with nationwide circulation from late 1949.

There were at least three reasons for this overshadowing and lack of interest. Firstly, it is unlikely that the Hungarian general public had any interest in the fate of the emigrants, it is even probable that the vast majority of them had simply no knowledge of the existence of this community at all. Secondly, the propaganda activities of the emigrants were aimed at the Yugoslav people and the South Slavic minorities in Hungary but not

25 MNL OL M-KS 276, f. 98, cs. 115, ő. e. 3-4.

26 MNL OL M-KS 276, f. 98, cs. 115, ő. e. 34-35.

27 Apart from the South Slavic department, Radio Budapest operated nine other foreign language sections, including the Italian, French, English, Spanish, Finnish, German, Austrian (sic!), Turkish and Greek sections. The Yugoslav section was one of the largest among them, after the Italian and the Greek sections. MNL OL M-KS 276, f. 98, cs. 115, ö. e. 75-76. For the ibeovci emigrants' role in the propaganda activities of Radio Budapest see: Vukman, "Harcban Tito és Rankovics klikkje ellen", 133-138. 
the native ethnic Hungarians as such. And thirdly, from the early 1950s, Yugoslavia as a topic was pushed into the background, although the economic and military assistance of the Western powers to Tito, some of the border incidents and a few desertions could cross the threshold of interest and could have some additional news value. ${ }^{28}$

A much greater number of articles written by the emigrants was published in Naše novine, the official journal of the Democratic Alliance of the Southern Slavs in Hungary. Based on my analysis, at least 26 emigrants were authors of one or more articles during the Soviet-Yugoslav conflict. The total of 90 articles written by ibeovci emigrants were published in Naše novine during this period, which means that it might have had an additional function as an emigrant paper. Exactly one third of the articles was published in 1951, while in 1952 and 1955, 18 and 16 articles were published, respectively. However, it is also true that these figures can only be considered high and significant if we compare them to the number of ibeovci emigrants. If we consider the total number of the authors and articles published in Naše novine, the number of emigrant authors and their articles was nearly insignificant. ${ }^{29}$

As to their content, the articles covered wide, and in some sense varied, topics, starting from the Soviet help in building the so called "peoples' democracies" and the "fight against the American imperialism" to the actual situation in Yugoslavia and the resistance against Tito's regime. Still, most of the articles written by the emigrants covered different domestic topics and minority issues, such as the "achievements" of the Hungarian internal policy, the "successes" of the planned economy, the "building of socialism", the agricultural "revolution", experiences of collectivization among the South Slavic minorities, their possibilities for education and their cultural organizations. In some cases, the author's actual employment reflected the topics of his articles. For example, Obrad Dobanovački, director of a grammar school in Budapest, wrote four articles on the current situation of South Slavic minority education and cultural achievements, Ahmed Seljahudin, a student of veterinary medicine,

28 Vukman, "Harcban Tito és Rankovics klikkje ellen", 138-143.

29 In his partial data handbook Danilo Urošević collected 5534 articles from 996 authors 996 for this period. (Dr. Danilo Urošević, A Naše novine válogatott repertóriuma - Selektivni repertorijum Naših novina, (Budapest: Szerb Országos Önkormányzat, 2000)). Therefore, the emigrants represented no more than 2.6 per cent of the authors and wrote 1.6 per cent of the articles. Most of the emigrants wrote only one or two articles, except for Ivan Mokuter who (also under the pseudonym Ivan Ivanović) wrote altogether 21 articles. Vukman, "Harcban Tito és Rankovics klikkje ellen", 147. 
summarized the annual stock farming exhibition, while Ivan Mokuter, Vlado Peteršić and Ljubomir Tomić could lure their literary talent with one or two poems and short novels. ${ }^{30}$ The topics covering the minority issues also implied that the emigrants had a role, although a minor one, in persuading the South Slavic population of Hungary about the importance of fighting against Tito and strengthening their stance against the Yugoslav leadership and supporting Rákosi in this conflict.

It was also Lazar Brankov who first suggested Rákosi to publish a local emigrant paper - to be more precise, to relocate the editorial board of Nova Borba to Budapest, but the emigrants own paper in Hungary, the Slovenian Za ljudsko zmago, was not published until 1 May 1951. The preparations for its publication intensified in the spring of 1951, after Moscow had put enough pressure on the HWP leadership. Even the organization of its editorial board was decided in the Soviet capital. Boris Verstovšek from the Prague emigrant community was appointed editor in chief; he arrived to Hungary solely for this reason. Other members of the editorial board were Gojko Trbović, Albert Svetina and Franc Majcen. ${ }^{31}$

It was published as a monthly paper first, but having taken the other emigrant papers as an example, the Department of International Relations of the Central Directorate of the HWP decided in the middle of August that it should be published three times a month. ${ }^{32}$ The next change took place by the order of the emigrants' Coordinating Committee from Moscow and Za ljudsko zmago became published as a weekly paper with increased number of pages from 15 October onwards. ${ }^{33}$ Its weekly publication became permanent, same as the numerous difficulties of editorial work. Some of these were material or financial, as it was quite difficult even to acquire a typewriter with special Serbo-Croatian characters or to repair the machines that had gone wrong. ${ }^{34}$ The cutting of costs that became necessary because of the current economic situation in Hungary reached the journal in January 1953. As a part of rationalization and opti-

30 Vukman, "Harcban Tito és Rankovics klikkje ellen", 147-148.

31 MNL OL M-KS 276, f. 65, cs. 105, ő. e. 69.

32 MNL OL M-KS 276, f. 98, cs. 146, ő. e. Versztovsek Borisz Bebrics elvtársnőnek. Budapest, 1951. augusztus 7. and Válasz Versztovsek elvtársnak. 1951. augusztus 17, [Boris Verstovšek to comrade Bebrics, 7 August 1951, and Reply to comrade Verstovšek, 17 August 1951].

33 MNL OL M-KS 276, f. 98, cs. 146, ő. e. Feljegyzés a titkárságnak. 1951. szeptember 18, [Note to the Secretariat, 18 September 1951].

34 MNL OL M-KS 276, f. 98, cs. 146, ő. e. Sátor János elvtársnak. 1953. szeptember 14, [To comrade János Sátor, 14 September 1953]. 
mization of cost efficiency, the subscription to different English-language papers was cancelled (as justification, the members of the editorial board could not understand them, either), private phone calls were forbidden, and fee payment was tightened, to name just a few measures. ${ }^{35}$ The lack of qualified and professional working force and the constant rotation among the staff resulted in more serious problems. The standard of submitted and published articles was regularly below the expected level of quality. It also turned out that even the emigrants themselves rarely read them. The new editors, too, lacked the necessary skills, and were short of routine and talent. They had to speak at least three languages - Serbian, Slovenian and Hungarian - perfectly, which caused serious hardship for most of them. The emigrants themselves were fully aware of this as the following short quotation clearly shows it: "To be honest, everyone in the editorial board lacks experience and aptitude to solve all the problems that appear during our work." 36

\section{Life under fourfold control. The emigrants and the State Protection Authority}

In the meantime, the emigrants lived and worked under fourfold control: (1) the emigrants' own leadership and summit organs in Moscow, (2) the Hungarian Workers' Party and its relevant departments, (3) their own local leadership in Hungary, and (4) the Hungarian State Protection Authority (ÁHV) that also kept them under constant surveillance. This hierarchical subordination and continuous surveillance practically excluded the slightest possibility of the emigrants' independent initiatives or the expression of their own opinion.

The most important decisions concerning and affecting all the emigrants' communities, including the one in Hungary, were made in Moscow by the emigrants own organisation, in close cooperation with, subordination to, and preadmission of the Foreign Relations Department of the Central Committee of the CPSU. If one important person should be singled out, that would be Pero Popivoda who controlled and organized many aspects of the lives and political activities of ibeovci emigrants in Hungary. He

35 MNL OL M-KS 276, f. 98, cs. 146, ő. e. Feljegyzés Bebrits elvtársnőnek. Budapest, 1953. január 13, [Minute to comrade Bebrits, 13 January 1953].

36 MNL OL M-KS 276, f. 98, cs. 146, ő. e. Jelentés a Za ljudsko zmago szerkesztőségének munkájáról 1952. október, [Report on the editorial work of Za ljudsko zmago, October 1952]. 
instructed the HWP and the emigrants' own leadership in Hungary many times. His polite request to Mátyás Rákosi were actually orders that the general secretary of the HWP did not dare to object to, most of the time.

One level below, in Hungary, the central organs of the HWP, including the Political Committee, Central Directorate and Secretariat, had an important say in questions related to the emigrants. Within this small circle of Communist politicians, Mátyás Rákosi remained the ultimate source of authority. On several occasions, the party leadership did not dare to make a decision on its own, but rather asked for Moscow's preliminary advice. Still, the cooperation and personal contacts between the Party and the emigrants were far from smooth; the latter repeatedly complained about their alleged negligence. On the second anniversary of the publication of the Bucharest resolution, on 28 June 1950, for everyday contact and the handling of the daily routine tasks, the Secretary of HWP created a South Slavic sub-department within the Department of Agitation and Propaganda Warfare of the Central Directorate with Sándor Szentivánszki as its head. It was probably his knowledge of the Croatian language that made him the most suitable person for this position. From March 1951, he entirely devoted his working hours to the emigrant-related issues. However, in January 1952, he was moved to a small company as a manager, and the ongoing issues were conveyed to the Department of Foreign Relations within the Central Directorate lead by Anna Bebrits. The department had already argued for this transformation, partly because this change should have been made in accordance with the changes that had taken place in the Soviet Union and its other Eastern European satellites, and partly because all problems and issues affecting the different political emigrant communities in Hungary (Yugoslav, Greek and Spanish) were dealt with at the same department. Everyday contact with the ibeovci emigrants was assigned to Sándor Kalmár in May 1952. Although, at first, the emigrants benefited from his work and had confidence in him, from 1953 on, everyday contact between Kalmár and the emigrants reduced significantly as the handling of the problems of the Greek and Spanish political emigrant communities were also assigned to him. For months, Kalmár was compelled to devote his energy entirely to the Spanish emigrants, therefore, he had no time to pay attention to the ibeovci emigrants. ${ }^{37}$

Moreover, the emigrants had their own leadership in Hungary. As it has already been mentioned, the first de facto leader of the emigrants

37 MNL OL M-KS 276, f. 55, cs. 190, 8; 55, cs. 205, ő. e. 4; 98, cs. 5, ő. e. 190; 98, cs. 139, ő. e. 84-85 and 151; Vukman, "Harcban Tito és Rankovics klikkje ellen", 119-123. 
was Lazar Brankov. It was again Brankov who insisted on the election of a leadership, but this first, three-member collective body was "elected" only after Brankov had already been arrested in Moscow in June 1949. Its members were Milutin Velemir, Gojko Trbović and Žarko Ljuboljev. Regardless of the ongoing scandals, the trio managed to keep their position nearly for a year; they were replaced by a five-member leadership on the congress of the ibeovci emigrants in Hungary on 13-14 May 1950. Its members were Đorđe Burgijašev, Albert Svetina, Dušan Grujić, Lajos Dudás and Kálmán Nyitrai. However, it was repeatedly reorganized and reshuffled - in accordance with the orders of the so-called Co-ordinating Committee, the governing body of the ibeovci emigrant communities in the Soviet Union and in Eastern Europe that time. On 12 February 1952, another, and again larger, leadership was created. It consisted of seven people, including Bogdan Pejović, Gojko Trbović, Franc Majcen, and Péter Berkes. Its head, as first among equals, was Boris Verstovšek. Only two of its members, namely Albert Svetina and Đorđe Burgijašev remained from the previous leadership, but these two people were arrested with prefabricated charges shortly afterwards. ${ }^{38}$ Because of the continuous scandals and ongoing reorganisation, it is not surprising that neither the emigrants themselves, nor the HWP's leadership had little trust in them. Therefore, the Secretariat of HWP asked the Alliance of Yugoslav Patriots, successor of the Co-ordinating Committee, in November 1953 to send someone "with great organizing skills" and "strong perception of politics" to lead the ibeovci community in Hungary. ${ }^{39}$ They never found such a person and it soon became a marginalized and neglected issue as the Soviet-Yugoslav relationship started its long and slow process of normalization. In February 1954, Rákosi finally tried to solve the problem with the appointment of a new, temporary committee. ${ }^{40}$

The forth element in the control of the ibeovci emigrants in Hungary came from the State Protecting Authority (ÁVH)..$^{41}$ The emigrants had a complex relation to the ÁVH. They were not able to make any decisions, however important or irrelevant they were, without the previous consent of the ÁVH. The emigrants first met their agents nearly immediately after they illegally crossed the border. As they emigrated for political reasons,

38 Vukman, "Harcban Tito és Rankovics klikkje ellen", 115-118, 123-124.

39 MNL OL M-KS 276, f. 54, cs. 280, ő. e. 5 and 79.

40 MNL OL M-KS 276, f. 54, cs. 307, ő. e. 27.

41 For the rather complex and ambiguous relationship between the emigrants and the ÁVH see: Vukman, "Harcban Tito és Rankovics klikkje ellen", 163-170. 
they tried to find the nearest border police station where they were interrogated by the border guard. Sometimes at least one inspector of the secret police was also present. If not, the refugee was interrogated separately shortly afterwards. These interrogations were necessary prerequisites for their affiliation with the emigrants' community. At later stages, at least one representative of their community participated in the interrogation process.

Apart from the individual motives and circumstances of going into exile, ÁVH agents were also interested in the Yugoslav economic and political situation, everyday hardship and living conditions, the anti-Titoist mood in general, and in the Yugoslav secret police (its aims, structure and working practices) in particular. Therefore, the emigrants were a useful source of information, especially in the early years of the Soviet-Yugoslav conflict. A number of emigrants were interrogated later, too, in connection with the internal personal conflicts, when a fellow emigrant was arrested (based on real or prefabricated charges) or after a Yugoslav agent had been caught.

In the meantime, the ÁVH also recruited agents among the emigrants and used them in investigation missions in the Yugoslav territory. Unfortunately, most of them failed and got caught by the Yugoslav border patrol or the State Security Administration (UDB), so the ÁVH stopped employing them for subversive activities in the Yugoslav territory in 1950. In some cases, after a successful mission, the recruited emigrants refused to go back to Yugoslavia. In other cases, the emigrants had to prove their anti-Titoist stance with these missions as a prerequisite for their admission to the ibeovci community. The ÁVH also recruited agents among the emigrants in order to spy their fellow members, which again referred to the lack of trust between the authorities and the emigrants. Personal and fraternal relations, acquaintances were useful features when the ÁVH was deciding whom to use as an agent. However, previous employment with the UDB or in officer ranks at the Yugoslav army would easily make the emigrants rather suspicious in the eyes of the Hungarian secret police. The ÁVH considered Branislav Živkov, the nephew of Lazar Brankov, its most useful agent, ${ }^{42}$ but it was Radovan Vrbica, who probably served the longest time as an ÁVH agent among the emigrants. The State Protection Authority used him under the code name "Micsunovics Vukó" until 26

42 ÁBTL 2.1. I/109-a, 335. For Branislav Živkov see also: ÁBTL 3.1.9. V-51967. 
June 1955. Shortly thereafter he was reactivated as an agent and his latest known post was in Sofia, in Bulgaria, in 1982. ${ }^{43}$

In order not to exaggerate the importance of the ibeovci emigrants, it is worth knowing that they represented only a tiny fraction among the agents and spies used by the ÁVH in Yugoslavia or for surveillance among the South Slavic minorities in Hungary. It is also true that the everyday presence of the security agents among the emigrants had a dual purpose: on the one hand, it ensured the safety of the emigrants (as they rightly feared of a possible attempt of assassination by the Yugoslavs), and on the other hand, it also meant their close observation. This paranoid atmosphere, where the enemies were seen everywhere and in everybody, surely sharpened the already existing fears, suspicion and mistrust both within the ibeovci community and between their community and the regime, as the following two short extracts clearly illustrate it. In his letter to Rákosi in December 1950, Milutin Velemir wrote about a "closed, pupated, and unnatural life" among the emigrants, which he traced back to the operational behaviour of the ÁVH: "it is not the spirit of the Hungarian Workers' Party that manifests itself among us, but that of the ÁVH. It has been imposed on us from the very beginning: remain silent, watch what you speak, do not talk on trams or buses as someone might notice that you are Yugoslav; nobody dared to say that he is a Yugoslav but a Bulgarian, a Greek or a Romanian, etc." He also objected that the members of the HWP never appeared among the emigrants (except for the emigrants' conferences and party courses), so they only had personal contact with the agents of the ÁVH. ${ }^{44}$ Two years later, Boris Verstovšek referred to similar problems: "The leadership [of the emigrants] is losing its reputation day by day as it seems to be needless and ridiculous in the eyes of the emigrants. [...] Based on the different manifestations of the comrades [e. g. leaders of the HWP], they [the emigrants] are of the opinion that the real leader or the community is comrade József Szabó, [...] who is responsible to the ÁVH; while the emigrants' leadership is nothing more than a puppet." 45

Finally, in connection with the emigrants and the State Protection Authority, it is impossible not to say a few words on the political show trials as they greatly affected the life and morale of ibeovci community in Hungary. As it has already been mentioned, Lazar Brankov was arrested in Moscow on 21 June 1949 based on prefabricated charges of being a Titoist

43 ÁBTL 3.2.1. Bt-290, 148.

44 MNL OL M-KS 276, f. 65, cs. 105, ő. e. 47.

45 MNL OL M-KS 276, f. 65, cs. 105, ő. e. 98-99. 
agent. The circumstances of his arrest were rather confusing. The Hungarian authorities had probably planned it in the spring of 1949 the latest, but the Soviet cadres objected to it first. He was interrogated in the Soviet capital, first on 8 and then on 16 July. His interrogation continued after he had been transferred to Hungary on 19 July 1949. After he had unsuccessfully tried to escape, Brankov crushed under the physical violence and moral blackmailing, and, as tertiary defendant providing the charges against Tito and the CPY leadership, he recited mechanically the set speech at Rajk's show trial that started on 16 September $1949 .{ }^{46}$ It is important to note here, that Rajk's trial, or to be more precise, the Rajk-Brankov trial as it was referred to in contemporary Hungarian sources, was not only an anti-Titoist trial but also served as a specimen for further show trials in Eastern Europe. At deliverance, Brankov was sentenced to life-long imprisonment for leading a Yugoslav conspiracy to subvert the Rákosi regime, for continuous intelligence activities and for being an abettor of the murder of Miloš Mojić that was carried out, according to the charges, by Živko Boarov, a Yugoslav diplomat at the Budapest embassy in the summer of 1948.

While in prison, Brankov was regularly interrogated and often used as a witness during the re-opening of other cases as the political climate eased after the spring of 1953. The authorities might have wanted him to play a key role in the trial of Gábor Péter, leader of the State Protection Authority, with whom he had an alleged espionage relationship with the code name „Dózsa”. It is important to note here that even if these were not recruitment and espionage in the conventional sense of the words, it was natural after 1945 that the members of the Communist parties thought it to be their "comradely duty" to provide the other fraternal parties, and especially the Communist party of the Soviet Union, with valuable information about their own countries. It is also important to understand that the political atmosphere of the time overshadowed not only the show trials but their rehearing, which pre-determined the judges' decisions. It often made difficulties for Brankov, too. Although it is also true that Brankov sent many telegrams to Belgrade under the above mentioned code name, but the nature and content of these telegrams suggest nothing secret or valuable for intelligence. ${ }^{47}$ Moreover, Brankov still re-

46 For the origins and proceedings of the trial in great detail see: Zinner Tibor, "A nagy politikai affér." A Rajk-Brankov-ügy, Vols I-II, (Budapest: Saxum, 2013-2014).

47 For example: AJ, F. 507, CK SKJ-75/I-2, br. 30, 30. 1. 1948; I-21, br. 207 and br. 208. 13. 6. 1948; I-23, 20. 6. 1948; II-38, 12. 4. 1948; III-33, 9. 9. 1948. - However, the papers 
mained in solitary confinement and was not allowed to meet other prisoners, receive visitors or be informed on the political changes. He was released by a presidential pardon on 3 April $1956 .{ }^{48}$

The second anti-Titoist trial involving ibeovci emigrants took place on 15-17 November 1952 after the commando members of László Bálint had been arrested. Their aim was to kidnap the leading members of the ibeovci community in Hungary one by one and illegally take them back to Yugoslavia. They were successful at first and managed to kidnap Dušan Vidović in mid-February 1952. Half a year later, Bálint's commando returned to Hungary and ensnared Boris Verstovšek on 11 September 1952, but the kidnappers were stopped and captured on 24 September in the vicinity of Szeged, not far from the Yugoslav-Hungarian border. The Hungarian authorities suspected that other fellow emigrants took part in Vidović's disappearance and nine people were arrested in a short period of time, including eight ibeovci emigrants. One of them (Emil Ognjenović) was released without a trial, another was beaten to death in custody (Đorđe Burgijašev), and the remaining six emigrants (Ozren Krstonošić, Branislav Doroslovački, Albert Svetina, Milutin Stevanović, Savo Novaković and Živorad Todorović) were sentenced in camera to 5 to 15 years of imprisonment on 17 and 24 September 1952. Although it must have become clear for the authorities themselves, after Verstošek's kidnapping, that the emigrants had nothing to do with the kidnappings, the internal logics of this paranoid system made their release impossible. They were discharged only on 7 March 1955. Their process of rehabilitation was prolonged into the mid-1960s, though. ${ }^{49}$

By that time Stalin had already been proclaimed dead (on 5 March 1953) and a slow and prolonged process of normalization between the Soviet Union and Yugoslavia had started. On 14 October 1954, as a gesture towards Tito, the Political Committee of the HWP decided to stop the political activities of ibeovci emigrants in Hungary and dissolved their organization. Their community lost its significance and during the follow-

confirming Brankov's role as the resident general of the UDB in Hungary before his emigration must have been among the non-researchable papers of the ministry of internal affairs.

48 Vukman, "Harcban Tito és Rankovics klikkje ellen", 187-194.

49 Péter Vukman, "Megfigyelés, beszervezés, koncepciós perek. Hat jugoszláv politikai emigráns és az állambiztonság (1948-1955). I. Származás, társadalmi háttér, emigráció", Betekintő 4, (2015), 1-18; Péter Vukman, “Megfigyelés, beszervezés, koncepciós perek. Hat jugoszláv politikai emigráns és az állambiztonság (1948-1955). II. A koncepciós per és következményei", Betekintő 1, (2016), 1-15. 
ing years, fewer and fewer emigrants remained politically active. Those who did, formed many groups along their different political and ideological views, personal and fraternal relations. A tiny faction preserved their anti-Titoist stance even in the 1970s and remained a hindrance to the normalization of relations between Yugoslavia and Hungary.

\section{Sources and Literature}

\section{Unpublished Sources}

- Historical Archives of the Hungarian State Security, Budapest: Section 2.1., Papers of the former Closed Archives (1945-1990); Section 3, Documents related to enquires and operational matters (19451990).

- The National Archives of Hungary (MNL OL), Budapest: XIX-J1-j, Ministry of Foreign Affairs, Yugoslavia, Secret Papers (19451964); XIX-J-1-k, Ministry of Foreign Affairs, Yugoslavia, General Papers (1945-1964); XI-J-4-a, Ministry of Foreign Affairs, Belgrade Embassy, Secret Papers (1947-1960); M-KS 276. f. Central organs of Hungarian Workers' Party (1946-1957).

- Archives of Yugoslavia (Arhiv Jugoslavije), Beograd. F. 507/IX-75, Međunarodna komisija, odnosi SKJ za stranim parijama, Mađarska (1945-1990).

Published Sources

- Gibianskii,Leonid."TheSovietBloc and the Initial Stage of the ColdWar. Archival Documents on Stalin's Meetings with Communist Leaders of Yugoslavia and Bulgaria, 1946-1948". Cold War International History Project Bulletin, March, (1998), 112-134.

- White Book on Aggressive Activities by the Governments of the USSR, Poland, Czechoslovakia, Hungary, Rumania, Bulgaria and Albania towards Yugoslavia. Beograd: Ministry of Foreign Affairs of the Federal People's Republic of Yugoslavia, 1951.

\section{Literature}

- $\quad$ Banac, Ivo. With Stalin against Tito. Cominformist Splits in Yugoslav Communism. Ithaka-London: Cornell University Press, 1988. 
- Dragišić, Petar. Jugoslovensko-bugarski odnosi 1944-1949. Beograd: Institut za noviju istoriju Srbije, 2007.

- Dragišić, Petar. "Napred - List jugoslovenskih emigranata (pristalica Kominforma) u Bugarskoj". Tokovi istorije 3-4, (2005), 125-142.

- Gibianski, Leonid. "The 1948 Soviet-Yugoslav Conflict and the Formation of the 'Socialist Camp' Model”. The Soviet Union in Eastern Europe, 1945-89, eds Odd Arne Westad, Sven Holtsmark, Iver B. Naumann, 26-46. New York: St. Martin's Press, 1994.

- Лубурић, Радојица. “Југословенска информбировска емиграција између илузија и стварности (1948-1953)”. Istorijski zapisi LXX, (1997), 1-26.

- Митровић, Момчило, Слободан Селинић. “Југословенска информбироовска емиграција у источноевропским земљама, 1948-1964". Tokovi istorije 1-2/2009, 31-54.

- Перишић, Мирослав. Од Стаљина ка Сартру. Формирање југословенске интелигенције на европским универзитетима 1945-1958. Београд: Завод за уџбенике, 2012.

- $\quad$ Perović, Jeronim. "The Tito-Stalin Split. A Reassesment in Llight of New Evidence". Journal of Cold War Studies 2, (2007), 32-63.

- Rajak, Svetozar. "The Cold War in the Balkans, 1945-1956", The Cambridge History of the Cold War, Vol. I, eds Melvyn P. Leffler, Odd Arne Westad, 198-220. Cambridge: Cambridge University Press, 2010.

- Selinić, Slobodan. Jugoslovensko-čehoslovački odnosi (1945-1955). Beograd: INIS, 2010.

- $\quad$ Urošević, Danilo. A Naše novine válogatott repertóriuma. Selektivni repertorijum Naših novina. Budapest: Szerb Országos Önkormányzat, 2000.

- Vojtěchovský, Ondřej. Iz Praga protiv Tita: Jugoslavenska informbiroovska emigracija u Čehoslovačkoj. Zagreb: Srednja Europa, 2016.

- Vojtěchovský, Ondřej. Z Prahy proti Titovi! Jugoslávská informbyrovská emigrace v Čehoslovensku. Praha: Univerzita Karlova v Praze, Filozofická fakulta, 2012.

- Vukman, Péter. "A Yugoslav Diplomat in Hungary: Lazar Brankov (1945-1949)". Vojvođanski prostor u kontekstu Evropske istorije, ur. Vladan Gavrilović, Svetozar Boškov, 513-524. Novi Sad: Filozofski fakultet u Novom Sadu, 2014.

- Vukman, Péter. "Harcban Tito és Rankovics klikkje ellen" Jugoszláv politikai emigránsok Magyarországon (1948-1980). Budapest-Pécs: ÁBTL-Kronosz, 2017. 
- Vukman, Péter. "Jugoslovenski politički emigranti u Mađarskoj (1948-1949)". Mađari i Srbi sa dve strane promenjive granice 19411948, Tematski zbornik radova, ur. Hornyák Árpád, Zoran Janjetović, Bíró László, 351-383. Budapest: MTA BTK Történettudományi Intézete, 2016.

- Vukman, Péter. "Lazar Brankov and the Yugoslav Communist Emigrants in Hungary (1948-49)". Razprave in Gradivo. Treatise and Documents, Vol. 73, No. 1, (2014), 67-85.

- Vukman, Péter. “Megfigyelés, beszervezés, koncepciós perek. Hat jugoszláv politikai emigráns és az állambiztonság (1948-1955). I.: Származás, társadalmi háttér, emigráció". Betekintő 4, (2015), 1-18.

- Vukman, Péter. "Megfigyelés, beszervezés, koncepciós perek. Hat jugoszláv politikai emigráns és az állambiztonság (1948-1955). II.: A koncepciós per és következményei”. Betekintő 1, (2016), 1-15.

- Vukman, Péter. "Négy óbecsei kommunista diplomata Magyarországon. Lazar Brankov, Živko Boarov, Branislav Doroslovački és Ozren Krstonošić politikai tevékenysége". Bácsország 2, (2011), 136-144.

- Zinner, Tibor. „A nagy politikai affér.” A Rajk-Brankov-ügy, I-II. Budapest: Saxum, 2013-2014. 


\title{
Резиме
}

Петер Вукман

\section{Политичке активности емиграната-ибеоваца у Мађарској (1948-1953)}

\begin{abstract}
Апстракт: Као последица избијања совјетско-југословенског конфликта настале су заједнице емиграната (ибеоваца) у Совјетском Савезу и његовим источноевропским сателитима, укључујући и Мађарску. Емигранти су били активно укључени у тадашњу антититовску пропагандну кампању. Овај чланак се фокусира на Лазара Бранкова, првог вођу емиграната-ибеоваца у Мађарској, његове политичке активности и улогу у организовању заједнице емиграната у овој земљи. Посебан нагласак стављен је на њихове пропагандне активности и однос између емиграната и мађарских власти. Основу чланка чине истраживања архивског материјала спроведена у Мађарском архиву.
\end{abstract}

Кључне речи: совјетско-југословенски конфликт, југословенско-мађарски односи, ибеовци, емигранти, Лазар Бранков

Као последица избијања совјетско-југословенског конфликта настале су заједнице емиграната (ибеоваца) у Совјетском Савезу и његовим источноевропским сателитима. Таква заједница основана је и у Мађарској крајем 1948. и почетком 1949. године. Њихов први вођа и организатор у Мађарској био је Лазар Бранков, бивши аташе југословенске амбасаде у Будимпешти. Мађарске власти искористиле су његову емиграцију како би дискредитовале југословенски систем и нагласиле одступање Титове политике од званичне совјетске линије. Одмах након емигрирања, Бранков се укључио у пропагандни рат против Југославије и организовање емигрантске заједнице у Мађарској.

Ова заједница је била инструмент пропагандног рата против Југославије јер су емигранти писали и ширили чланке у емигрантским новинама и учествовали у дневним радио-преносима у Југославији. Њихове активности нису текле без потешкоћа, нити се пропагандни рат против Тита сводио само на њихове активности. За 
мађарске власти, они су били значајни као релативно јефтино оруђе које се могло лако користити без страха од ширења постојећих сукоба. Емигранти су живели под четвороструком контролом и имали прилично сложен и вишесмислен однос са Управом државне безбедности. Параноидна атмосфера Ракошијевог режима заоштрила је већ постојеће страхове, сумње и неповерење и унутар емигрантске заједнице и између ње и мађарских власти. Политичко суђење Лазару Бранкову и другим емигрантима такође је у великој мери утицало на морал ове заједнице. 